Historic, Archive Document

Do not assume content reflects current scientific knowledge, policies, or practices. 



\section{Shipping Containers of Standard Size for Lettuce, Nectarines, Peaches, and Strawberries}

U.S. Department of Agriculture

Science and Education Administration

Advances in Agricultural Technology • AAT-W-11/June 1980 
This publication is available from the Market Quality and Transportation Research Laboratory. P. 0. Box 8143 , Fresno, CA 93747.

International Standard Serial Number (ISSN) 0193-3736

Science and Education Administration, Advances in Agricultural Technology, Western Series, No. 11, June 1980 


\section{ABSTRACT}

Use of shipping containers of four standard lengths and widths that fit on the international $120-$ by $100-\mathrm{cm}$ (47.3- by 39.4-inch) pallet base would facilitate marketing of fresh fruits and vegetables in the United States. The large number of different sizes of fresh fruit and vegetable containers that now arrive at supermarket warehouses and wholesale markets, contribute to high packaging and handling costs, container damage, and product loss. Much of this damage and loss occurs because different shapes and sizes of packages are handled during distribution to retail stores.

This report discusses possible standard outside lengths and widths for containers to be used for shipping fresh peaches, nectarines, lettuce, and strawberries on a standard metric base of 120 by $100 \mathrm{~cm}$. Use of containers with modular sizes that fit this metric base for other fresh fruits and vegetables would help to make all such containers compatible with one another.

A 50- by 30-cm (19.7- by 11.8-inch) shipping container would be suitable for peaches and nectarines, whereas either a 60- by 40-cm (23.6- by 15.7-inch) or 50by 40-cm (19.7- by 15.7-inch) shipping container is suitable for lettuce. A $50-$ by $40-\mathrm{cm}$ tray is suitable for strawberries. The depths of containers may vary to accommodate the product. 


\section{CONTENTS}

\section{Page}

Introduction............................. 1

Peaches and nectarines.................... 4

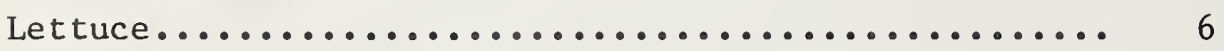

Strawberries............................. 10

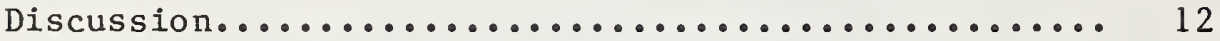




\title{
SHIPPING CONTAINERS OF STANDARD SIZE FOR LETTUCE, NECTARINES, PEACHES, AND STRAWBERRIES
}

\author{
By R. Tom Hinsch and Roger E. Rij
}

\section{INTRODUCTION}

With the costs of packaging, handling, and transportation climbing ever higher, it becomes increasingly important to standardize shipping containers so that they can be efficiently handled at their points of origin and destination where they will be intermingled with other containers. On this basis, the U.S. fresh fruit and vegetable industry should consider the task of standardizing its shipping containers to fit on bases with metric dimensions of 120 by $100 \mathrm{~cm}$ ( 47.2 by 39.4 inches). About 550 different types and sizes of containers are in use for 49 different fresh fruits and vegetables. 2 Included are 5 different container sizes for peaches, 2 for nectarines, 27 for lettuce, and 5 for strawberries. The principal factors that have influenced the shape and dimensions of containers are: (1) volume should be sufficient to accommodate a given weight; (2) size should be sufficient to make maximum use of available space (cube) in transport vehicles; (3) size should be compatible with requirements for refrigerated air circulation in loads; and (4) materials should be efficiently used for making any given style of container. Containers are not necessarily designed to provide the best handling methods throughout the entire marketing system.

Not all of the factors enumerated are currently considered in the design of containers; however, designers generally have not included standardization with other containers in their work. Also, they usually have not considered how the handling of one size of a container meshes with containers of other sizes during repeated handling throughout the marketing system. The shipping containers used presently for diverse fresh fruits and vegetables can not be efficiently comingled on the same pallets during transfer from receiving warehouse to retail store because their many sizes and shapes are not compatible (fig. 1).

${ }^{1}$ Agricultural marketing specialists, Market Quality and Transportation Research, Science and Education Administration-Agricultural Research, U.S. Department of Agriculture, 2021 S. Peach Avenue, P.0. Box 8143, Fresno, Calif. 93747.

${ }^{2}$ Stokes, D. R., and Woodley, G. W. Standardization of shipping containers for fresh fruits and vegetables. U.S. Department of Agriculture Marketing Research Report No.911, 118 p. 1974. 


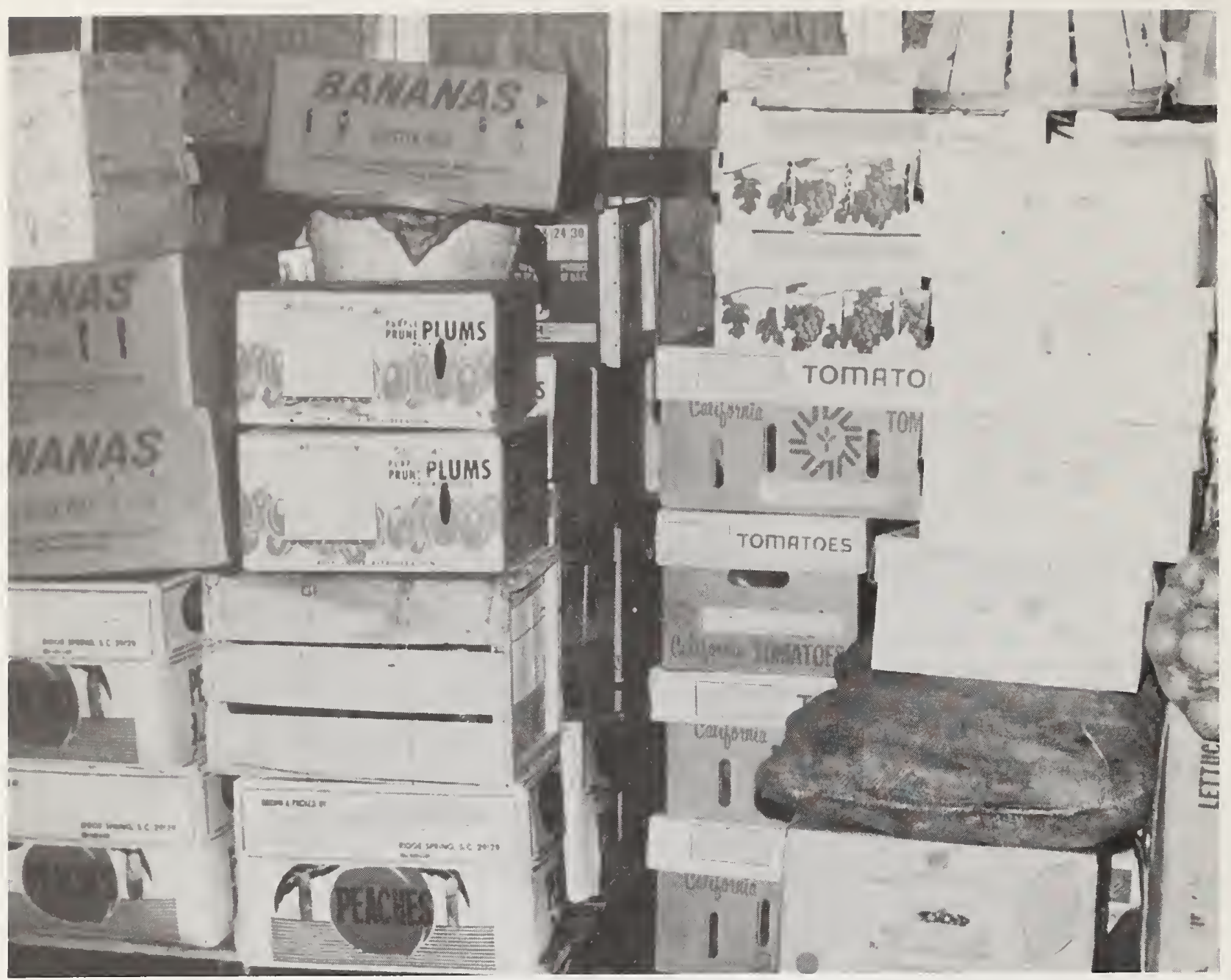

Figure 1.--Typical array of shipping containers for delivery to retail store. Incompatibility in sizes and shapes leads to difficulties in stacking.

Standardization is in progress, but has been slow, even though many trade organizations have endorsed the 121.9- by 101.6-cm (48- by 40-inch) pallet base. The United Fresh Fruit and Vegetable Association (UFFVA) has endorsed the 48- by 40-inch pallet, but for products shipped on slip sheets UFFVA has endorsed a base size of 120 by $100 \mathrm{~cm}$ ( 47.2 by 39.4 inches). This is the base size for international trade recommended in Document 85, Recommendations on the International Standardization of Packaging for Fruits and Vegetables, issued by the Organization for Economic Cooperation and Development (OECD). OECD also recommended four standard metric shipping containers (fig. 2). Their outside lengths and widths are:

$$
\begin{aligned}
& \text { 1. } 60 \text { by } 40 \mathrm{~cm}(23.6 \text { by } 15.7 \text { inches }) \\
& \text { 2. } 50 \text { by } 40 \mathrm{~cm}(19.7 \text { by } 15.7 \text { inches }) \\
& \text { 3. } 50 \text { by } 30 \mathrm{~cm} \text { ( } 19.7 \text { by } 11.8 \text { inches }) \\
& \text { 4. } 40 \text { by } 30 \mathrm{~cm} \text { ( } 15.7 \text { by } 11.8 \text { inches })
\end{aligned}
$$



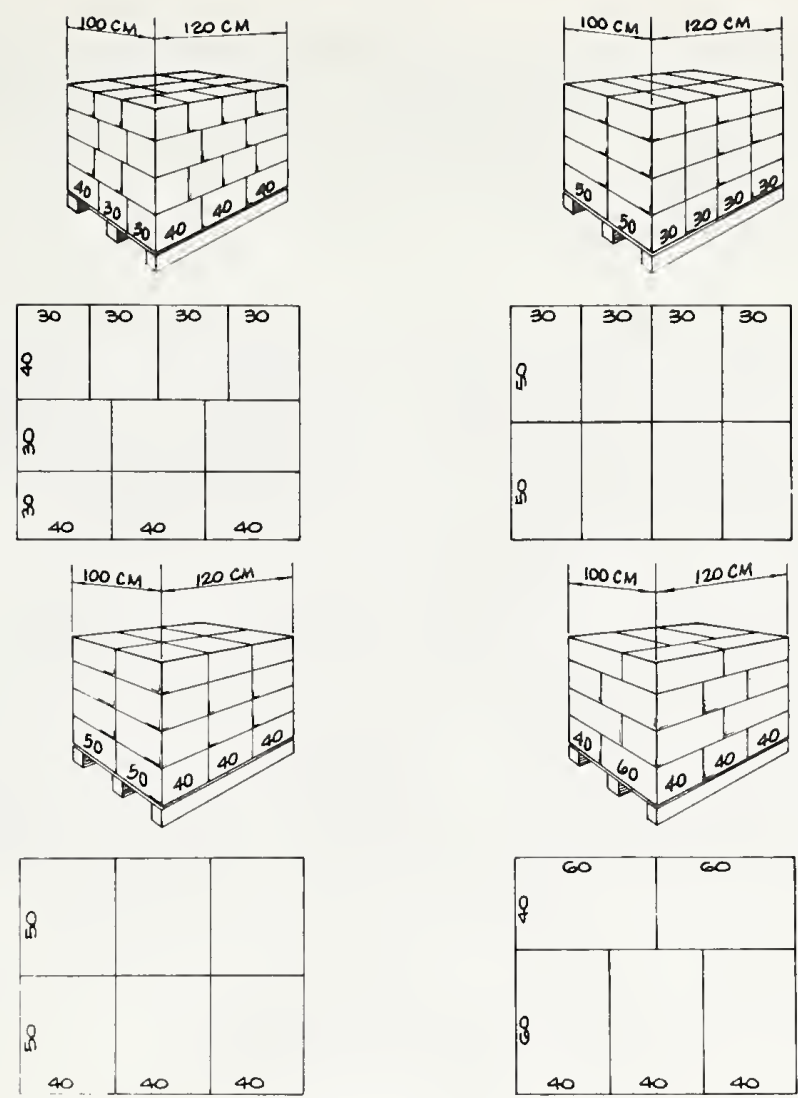

Figure 2.--Stacking patterns for each of the recommended size containers on a 120 - by $100-\mathrm{cm}(47.2-$ by $39.4-\mathrm{inch})$ base.

The depth of the container could vary, depending on the commodity packed. All dimensions given in the report are outside unless otherwise stated.

With the increased use of highway trucks (about 90 percent of fresh fruits and vegetables are transported to market by truck), a metric pallet of 120 by $100 \mathrm{~cm}$ ( 47.2 by 39.4 inches) becomes practical as it will nearly fill the new refrigerated trailers with inside widths up to $231.1 \mathrm{~cm}$ (91 inches).

Previous work 34 has shown the feasibility of packing and shipping table grapes in 50- by 40-cm (19.7- by 15.7-inch) containers and cherries in 50- by 30-cm (19.7- by 11.8-inch) shipping containers. Furthermore, McIntosh and Golden Delicious apples exported in metric shipping containers showed no more bruising than those shipped in the commonly used containers. 5

${ }^{3}$ Hinsch, R. T., and Rij, R. E. Feasibility of shipping California table grapes in fiberboard and polystyrene foam boxes and in polyethylene mesh bags. U.S. Department of Agriculture, Marketing Research Report No. 871, 12 p. 1970 . ${ }^{4}$ Hinsch, R. T., Fountain, J. B., and Rij, R. E. New shipping containers for fresh western cherries, costs, performance, and trade acceptance. U.S. Department of Agriculture, Marketing Research Report No • 902, 12 p. 1971.

${ }^{5}$ Mallison, E. D., and Stokes, D. R. Feasibility of using a 50- by 30centimeter cell box for exporting McIntosh and Golden Delicious apples. U.S. Department of Agriculture, Marketing Research Report No. 847, 16 p. 1970. 
Florida grapefruit were less deformed when shipped to Japan in 50- by 30by $25.4-\mathrm{cm}$ ( $19.7-$ by $11.8-$ by 10-inch) boxes, which permitted them to be unitized on $120-$ by $100-\mathrm{cm}$ (47.2- by 39.4-inch) pallets, than when they were shipped in conventional boxes that were hand-stacked in ships' holds. 6 The conventional boxes trad inside dimensions of 43.2 by 27 by $25.7 \mathrm{~cm}$ ( 17 by 10.6 by 10.1 inches).

Studies on western peaches, nectarines, lettuce, and strawberries were made to determine only the shipping container size and the quantity of each product that would fit in metric-size containers. Shipments with these products were not made. The size containers chosen for each commodity are the ones that come closest to holding the same amount of product that is presently being shipped by that industry. For peaches and nectarines, the net weights of containers were determined for various sizes of these fruits. The quantity of fruit, sold on a count or piece basis in the past, has been changed to a weight basis in volumefilled containers in the last few years. This should reduce the resistance to change if the capacity of the metric containers is about the same as conventional containers. Lettuce, which is not normally sized when it is naked packed, was trimmed to fit in two sizes of metric containers. Strawberry consumer units were redesigned to allow for liter and one-half liter size units, as well as new pint and quart size units being designed to fit in the metric size shipping tray.

\section{PEACHES AND NECTARINES}

Western peaches and nectarines are most commonly shipped in boxes that are volume filled with 25 pounds of fruit. These fruits are shipped in corrugated fiberboard bliss or tray-style boxes with the following outside dimensions: 17 $1 / 2$ inches long by 14 inches wide, $53 / 4$ to $63 / 4$ inches deep ( 44.5 by 35.6 by 14.6 to $17.1 \mathrm{~cm})$. The length and width of this container was adopted many years ago because it used the available space in the ice bunker railcar most effectively for hand-stacked loads. This container size also could be stacked efficiently on $106.7-$ by $88.9-\mathrm{cm}$ ( $42-$ by 35-inch) pallets, which almost fully used the floorspace available in mechanically refrigerated railcars and refrigerated highway trucks.

In our tests, peaches and nectarines were volume filled into containers 50 by $30 \mathrm{~cm}$ ( 19.7 by 11.8 inches) and 50 by $40 \mathrm{~cm}(19.7$ by 15.7 inches). We used these sizes because western peaches are now commonly shipped in volume filled boxes that approximate these sizes. Six fruit sizes were packed; these ranged from size 88 to size 56, $21 / 4$ to $27 / 8$ inches, respectively. The boxes were $16.5 \mathrm{~cm}$ ( 6.5 inches), $19.0 \mathrm{~cm}$ ( 7.5 inches) or $20.0 \mathrm{~cm}$ ( 7.9 inches) deep and contained from 23.5 pounds ( 10.5 kilograms) to 34.5 pounds ( $15.5 \mathrm{kilograms})$ of fruit (tables 1 and 2 ).

6 Hale, P. W., Smoot, J. J., and Miller, W. R. Use of the international standard 50 × 30 centimeter shipping containers for the export of grapefruit. Proceedings of the Florida State Horticultural Society 91:133-136. 1978. 
Table 1.--Weights of various sizes of peaches and nectarines packed in boxes that are $50 \mathrm{~cm}$ long, $30 \mathrm{~cm}$ wide (19.7 by 11.8 inches) and have 3 depths

Fruit size

\begin{tabular}{|c|c|c|c|c|c|c|c|}
\hline \multirow{2}{*}{$\frac{\text { Count }}{\text { No. }}$} & Diameter & \multicolumn{2}{|c|}{$\begin{array}{c}16.5 \mathrm{~cm} \\
(6.5 \text { inches })\end{array}$} & \multicolumn{2}{|c|}{$\begin{array}{c}19.0 \mathrm{~cm} \\
\text { ( } 7.5 \text { inches) }\end{array}$} & \multicolumn{2}{|c|}{$\begin{array}{c}20.0 \mathrm{~cm} \\
(7.9 \text { inches })\end{array}$} \\
\hline & Inches & $L b$ & $K g$ & $L b$ & $K g$ & $L b$ & $K g$ \\
\hline 88 & $21 / 4$ & 26.0 & 11.7 & 30.0 & 13.5 & 33.0 & 14.8 \\
\hline 80 & $23 / 8$ & 23.5 & 10.5 & 28.5 & 12.8 & 33.5 & 15.0 \\
\hline 72 & $27 / 16$ & 25.9 & 11.7 & 28.5 & 12.8 & 34.5 & 15.5 \\
\hline 64 & $25 / 8$ & 24.0 & 10.8 & 29.0 & 13.0 & 32.5 & 14.6 \\
\hline 60 & $213 / 16$ & 24.5 & 11.0 & 25.5 & 11.5 & 31.5 & 14.0 \\
\hline 56 & $27 / 8$ & 24.5 & 11.0 & 29.0 & 13.0 & 31.0 & 14.0 \\
\hline Average & weight & 24.7 & 11.0 & 28.4 & 12.7 & 32.6 & 14.6 \\
\hline
\end{tabular}

Container depth

$19.0 \mathrm{~cm}$
$(7.5$ inches $)$

( 7.9 inches)

Table 2.--Weights of various sizes of peaches and nectarines packed in boxes that are $50 \mathrm{~cm}$ long by $40 \mathrm{~cm}$ wide (19.7 by 15.7 inches) and have 3 depths

Fruit size

$\longrightarrow$

Count Diameter
Container depth

$\begin{array}{ccc}16.5 \mathrm{~cm} & 19.0 \mathrm{~cm} & 20.0 \mathrm{~cm} \\ (6.5 \text { inches }) & (7.5 \text { inches }) & (7.9 \text { inches })\end{array}$

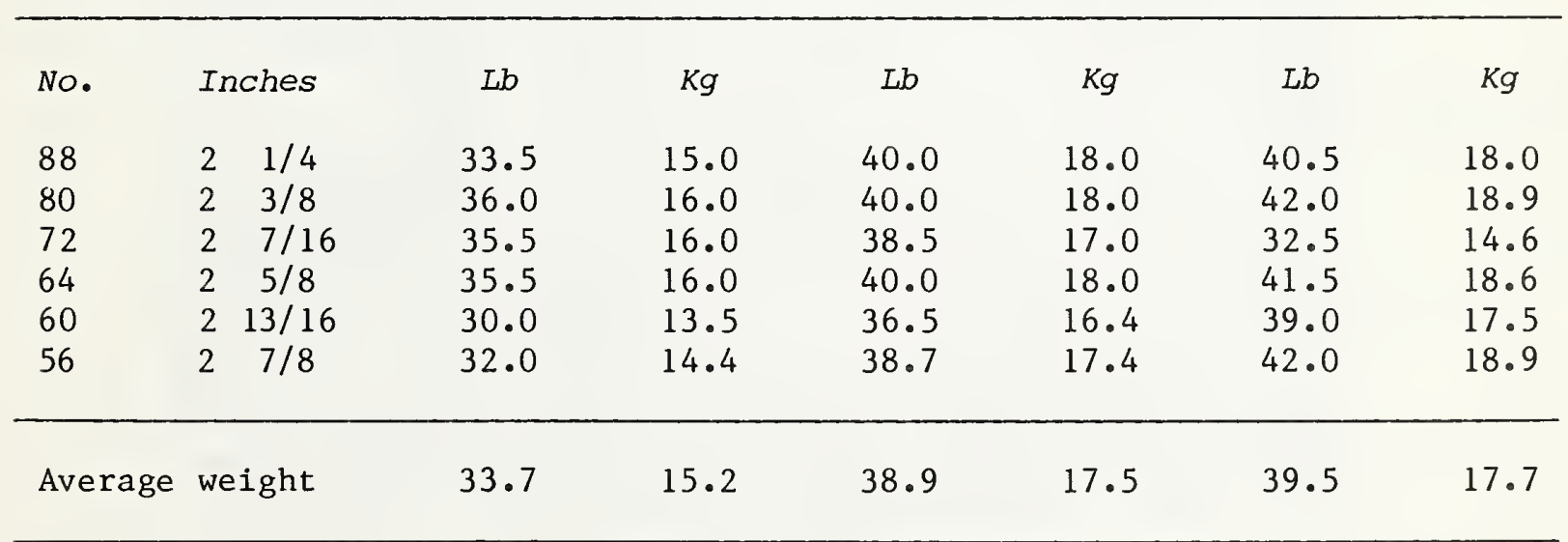




\section{LETTUCE}

Naked (nonwrapped) western iceberg lettuce is marketed in corrugated fiberboard, regular slotted containers with inside dimensions of 21.5 inches long by 16.1 inches wide, and 10.7 inches deep ( 54.6 by 40.9 by $27.2 \mathrm{~cm}$ ). Normally, 24 heads are packed in this box, even though the size of iceberg lettuce heads vary greatly. As a result, the lettuce boxes frequently are overpacked, which causes the side and end panels to bulge. Therefore, when we developed packing patterns for lettuce, several patterns were chosen for two container sizes, so the lettuce would fit properly into the container for which it was designed.

The boxes for lettuce we studied were $60 \mathrm{~cm}$ long, $40 \mathrm{~cm}$ wide, and $30 \mathrm{~cm}$ deep ( 23.6 by 15.7 by 11.8 inches) or $50 \mathrm{~cm}$ long, $40 \mathrm{~cm}$ wide, and $30 \mathrm{~cm}$ deep ( 19.7 by 15.7 by 11.8 inches). All measurements are outside dimensions.

We selected heads with diameters that represent most commercially marketed sizes: (1) large 14.0 to $16.5 \mathrm{~cm}$ ( 5.5 to 6.5 inches); (2) medium 11.4 to 14.0 $\mathrm{cm}$ ( 4.5 to 5.5 inches); and (3) small 10.2 to $12.7 \mathrm{~cm}$ ( 4 to 5 inches). Occasional bulging may occur with these sizes of heads, depending on their density. Smaller or larger heads may be marketed, but only during unusual marketing conditions, such as those caused by unfavorable weather.

The two container sizes and three lettuce sizes are shown in figures 3 through 8, and they are described in tables 3 and 4 .

Text continues on page 10 .

Table 3.--Number of heads per box and packing patterns for various sizes of western iceberg lettuce packed in fiberboard containers with outside dimensions of 60 by 40 by $30 \mathrm{~cm}$ (23.6 by 15.7 by 11.8 inches)

Head size and diameter

Heads per box

Patter $n^{i}$

Layers

No.

No.

Large :

14.0 to $16.5 \mathrm{~cm}$

24

$4 / 3$

2

(5 $1 / 2$ to $61 / 2$ inches)

Medium:

11.4 to $14.0 \mathrm{~cm}$

(4 $1 / 2$ to $51 / 2$ inches)

30

$5 / 3$

2

Sma11:

10.2 to $12.7 \mathrm{~cm}$

40

$5 / 3$

23

( 4 to 5 inches)

${ }^{1}$ Number of heads long by number of heads wide in the container.

2 The middle layer is packed 2 heads wide by 5 heads long . 


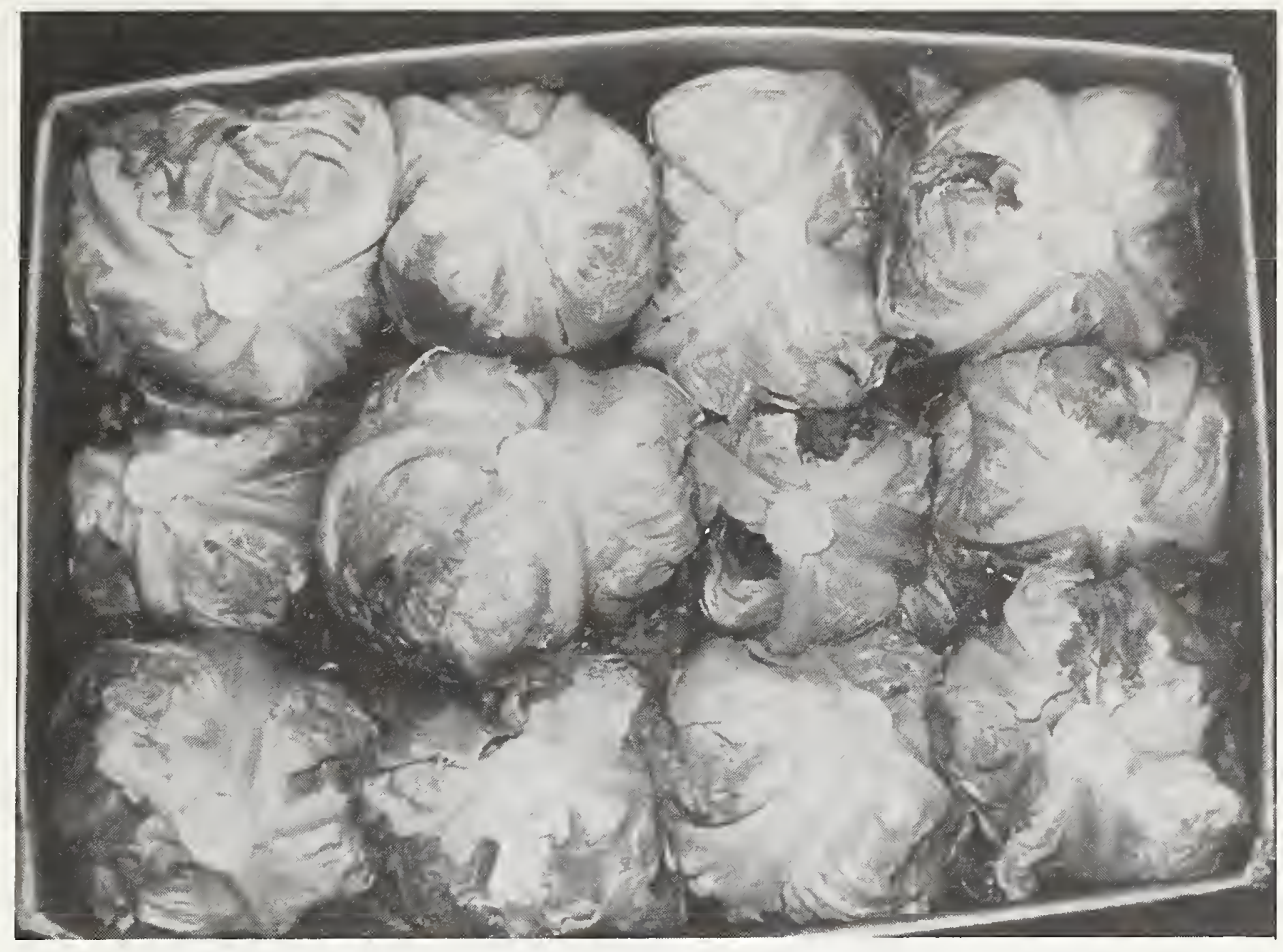

Figure 3.--Large lettuce heads packed in $60-$ by $40-$ by $30-\mathrm{cm}$ (23.6- by $15.7-$ by 11.8-inch) container. Each of the two layers are packed 3 heads wide by 4 heads long for a total of 24 heads per container.

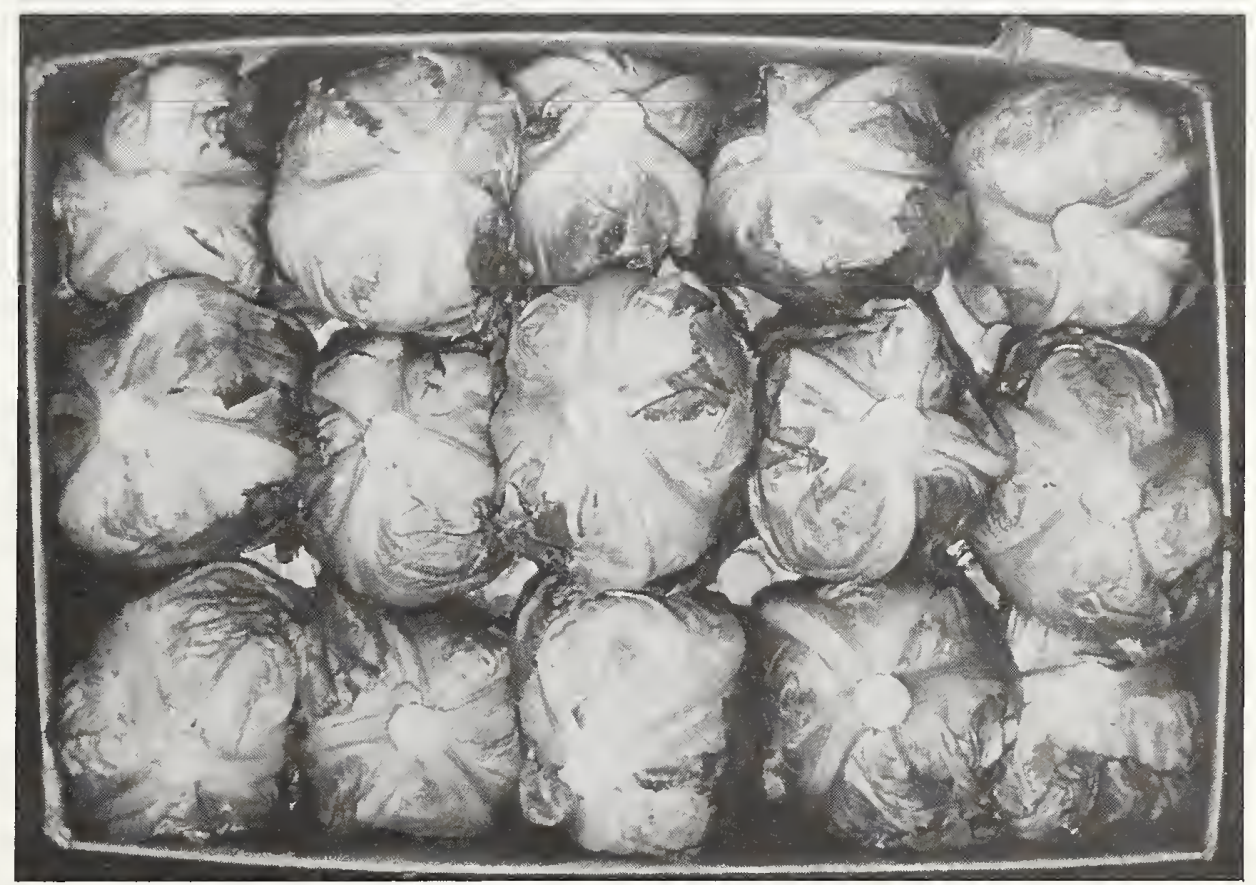

Figure 4.--Medium lettuce heads packed in $60-$ by $40-$ by $30-\mathrm{cm}$ (23.6- by 15.711.8-inch) container. Each of the 2 layers are packed 3 heads wide by 5 heads long for a total of 30 heads per container. 


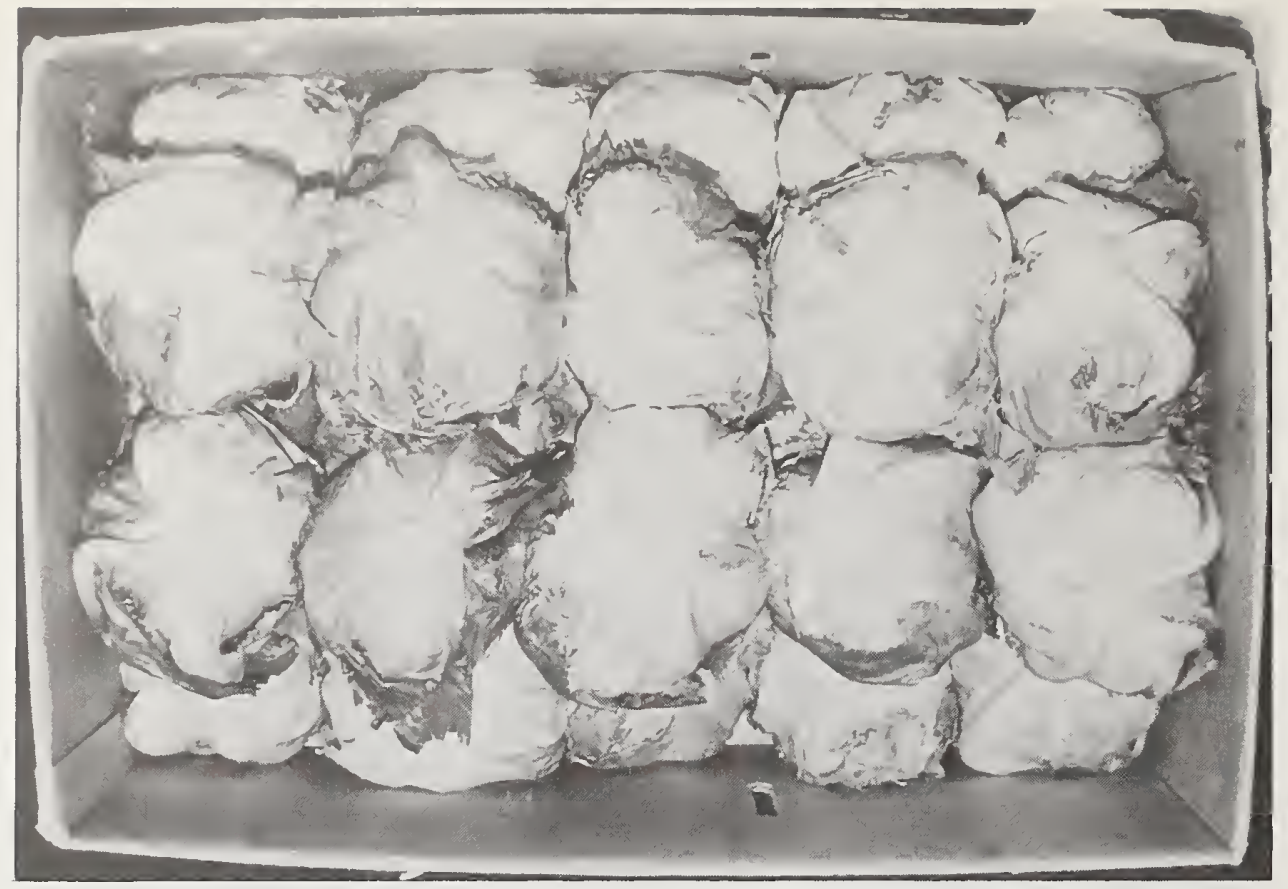

Figure 5.--Small lettuce heads packed in $60-$ by $40-$ by $30-\mathrm{cm}$ (23.6- by $15.7-$ by 11.8 -inch) container. The top and bottom layers are packed 3 heads wide by 5 heads long. The middle layer is packed 2 heads wide by 5 heads long for a total of 40 heads per container.

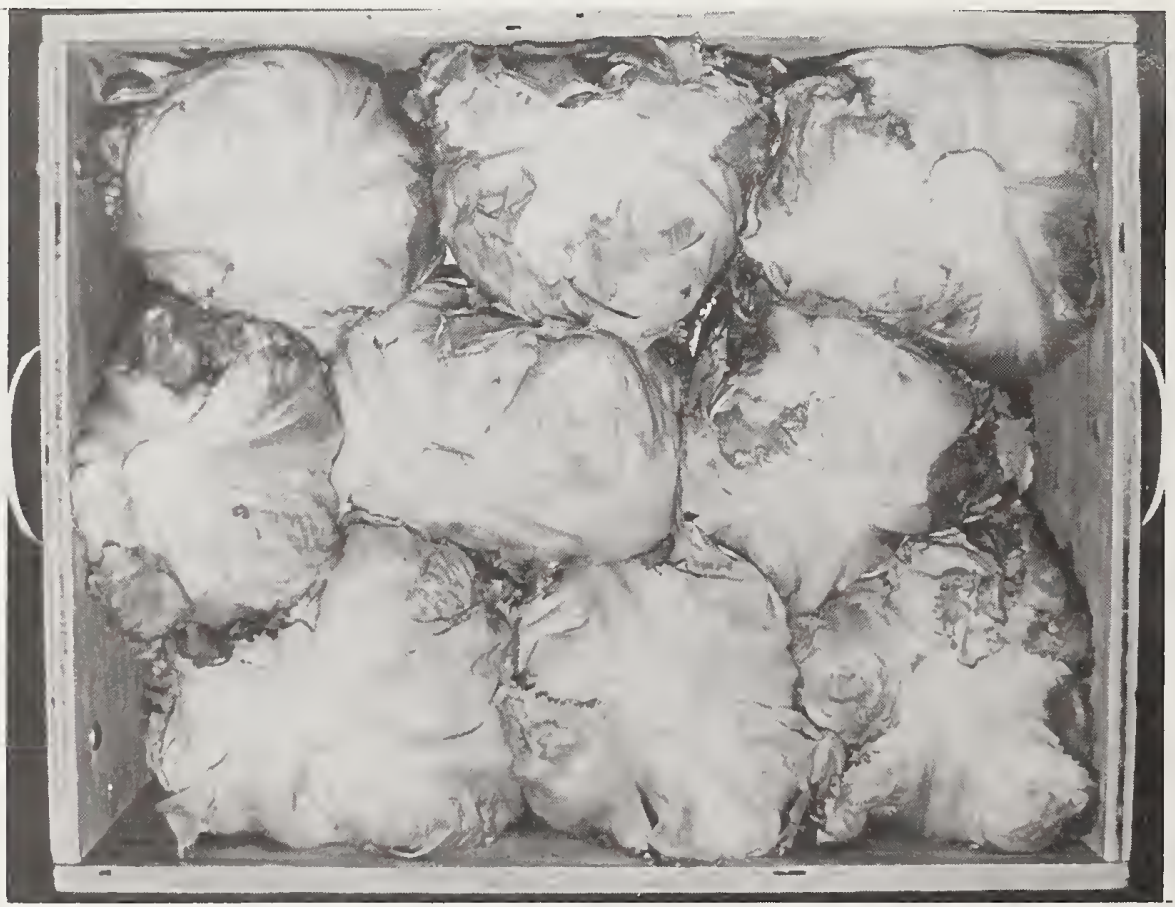

Figure 6.--Large lettuce heads packed in 50- by 40- by 30-cm (19.7- by 15.7by 11.8-inch) container. Each of the 2 layers are packed in a triangular pattern for a total of 18 heads per container. 


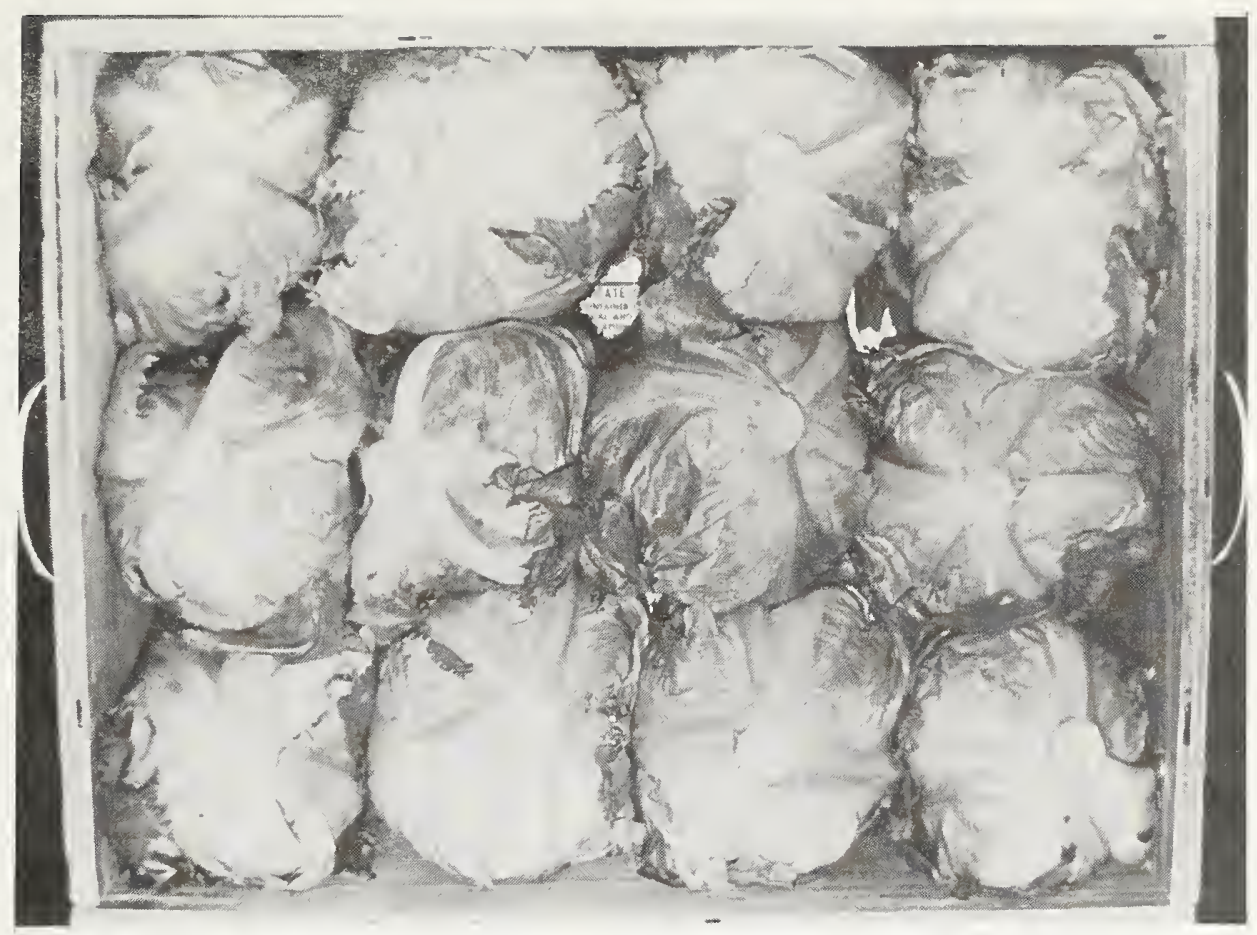

Figure 7.--Medium lettuce heads packed in 50- by 40- by 30-cm (19.7- by 15.7by 11.8-inch) container. Each of the 2 layers are packed 3 heads wide by 4 heads long for a total of 24 heads per container.

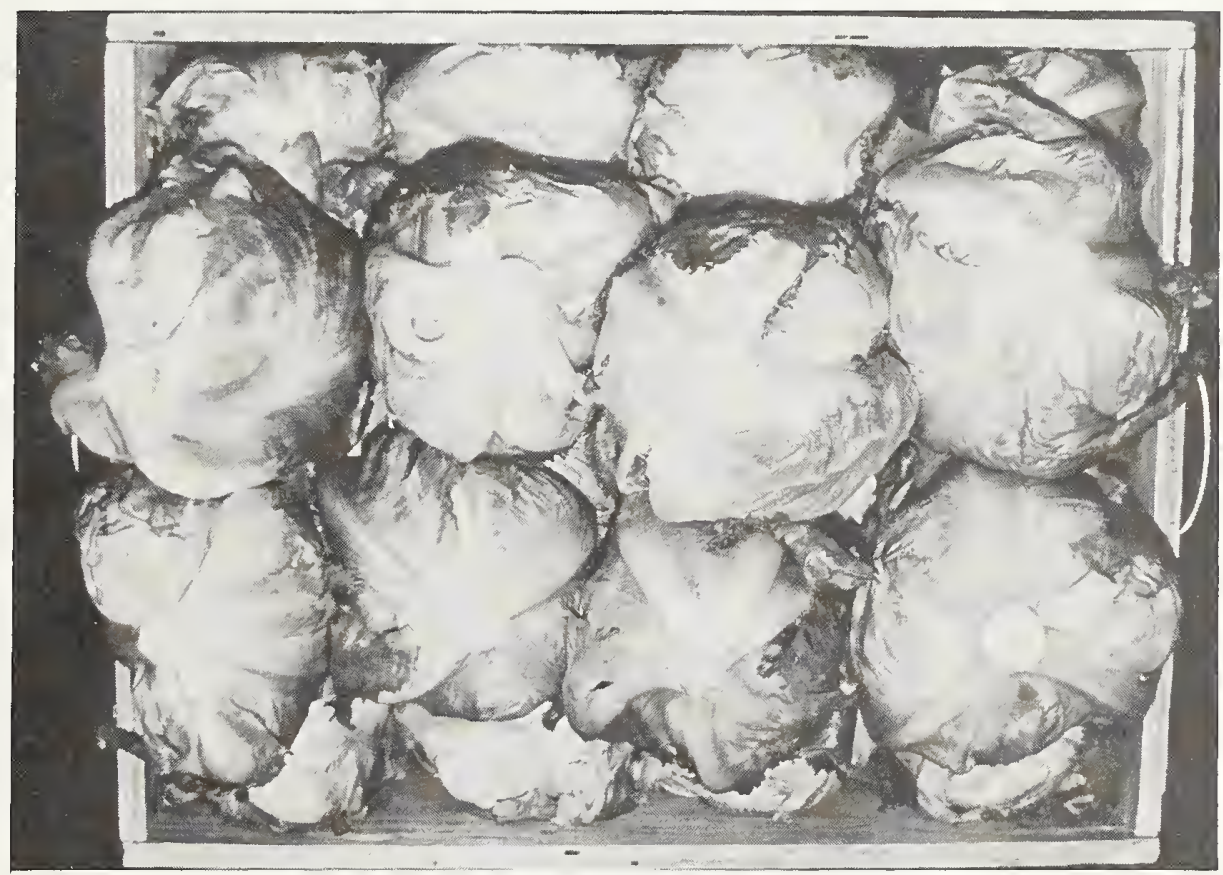

Figure 8.--Small lettuce heads packed in 50 - by $40-$ by $30-\mathrm{cm}$ (19.7- by $15.7-$ by 11.8-inch) container. Both the top and bottom layers are packed 3 heads wide by 4 heads long. The middle layer is packed 2 heads wide by 4 heads long for a total of 32 heads per container. 
Table 4.--Number of heads per box and packing patterns for various sizes of western iceberg lettuce packed in fiberboard containers with outside dimensions of 50 by 40 by $30 \mathrm{~cm}$ ( 19.7 by 15.7 by 11.8 inches)

\section{Large:}

No.

No.

14.0 to $16.5 \mathrm{~cm}$

(5 $1 / 2$ to $61 / 2$ inches)

18

$3 / 3$

2

Medium:

11.4 to $14.0 \mathrm{~cm}$

( $41 / 2$ to $51 / 2$ inches)

24

$4 / 3$

2

Small:

10.2 to $12.7 \mathrm{~cm}$

32

$4 / 3$

23

( 4 to 5 inches)

${ }^{1}$ Number of heads long by number of heads wide in the container.

2 The middle layer is packed 2 heads wide by 5 heads long.

\section{STRAWBERRIES}

California strawberries are mostly packed in pint baskets (0.55 L), 12 of which are packed in corrugated fiberboard trays. The trays have a center divider but do not have a cover. Their outside dimensions are: length, 19.3 inches; width, 13 inches; depth, 4.1 inches ( 49 by 33 by $10.9 \mathrm{~cm}$ ). The trays are stacked on 39- by 39-inch ( 99.1 - by $99.1-\mathrm{cm}$ ) pallets, 6 trays to a layer, 72 trays per pallet.

We selected a tray that was $50 \mathrm{~cm}$ long by $40 \mathrm{~cm}$ wide ( 19.7 by 15.7 inches) because these dimensions are close to those of the present strawberry tray (figs. 9 and 10). The tray would have inside dimensions of $183 / 4$ inches long by 14 $7 / 8$ inches wide by $33 / 32$ inches deep $(47.6$ by 37.8 by $7.1 \mathrm{~cm}$ ). The corrugated divider would run lengthwise and be three-eighths of an inch $(0.95 \mathrm{~cm})$ wide. The depth would depend on whether the individual consumer units packed in the trays were pints, quarts, liters, or one-half liters.

The individual consumer units are proposed to be pints, quarts, liters, or one-half liters. All of the consumer units would be rectangular and tapered from the top to the bottom. Their proposed dimensions are shown in table 5 . 

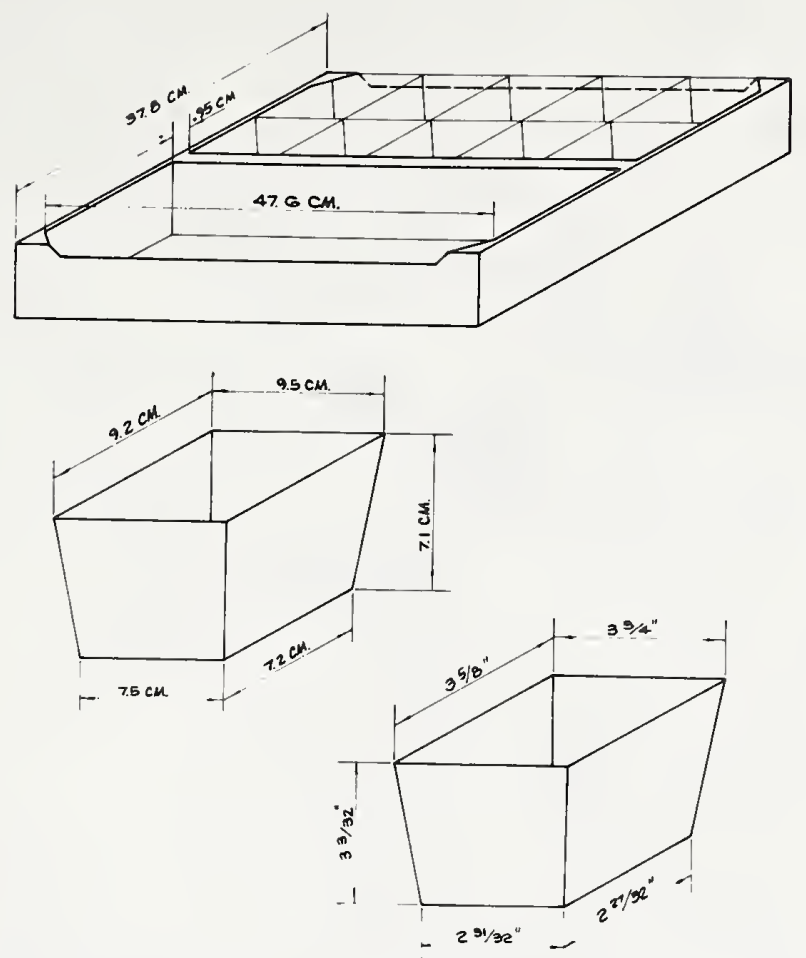

Figure 9.--Packing scheme and dimensions of pint or one-half liter baskets of strawberries packed in a fiberboard tray.
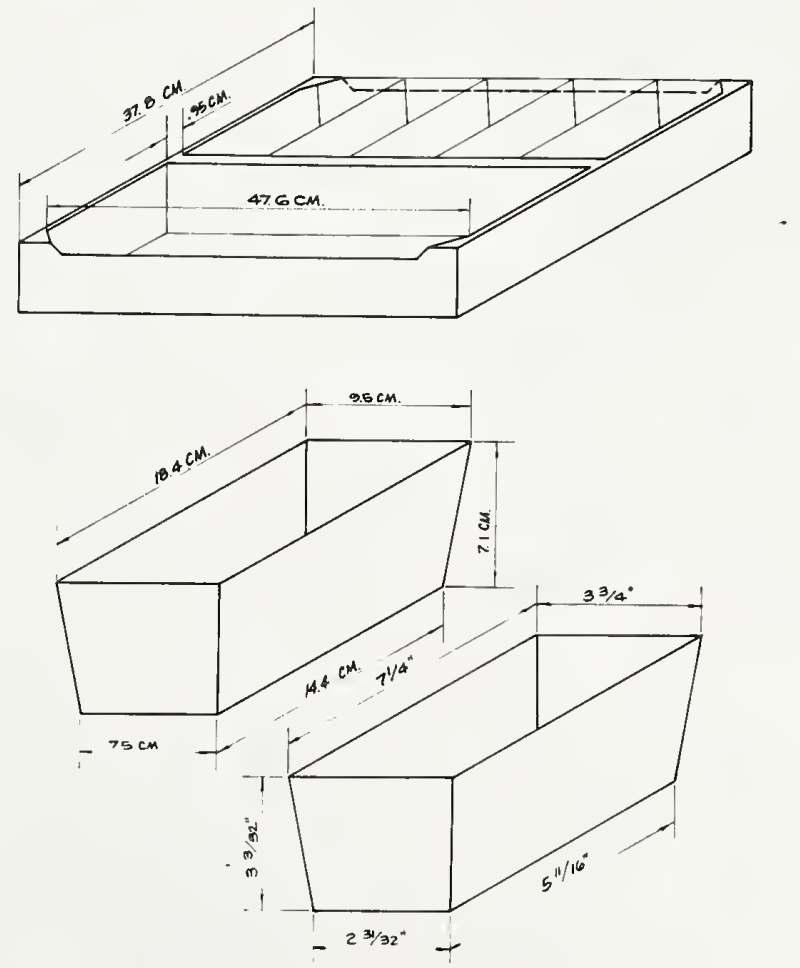

Figure 10.--Packing scheme and dimensions of quarts or liter baskets of strawberries packed in a fiberboard tray. 
Table 5.--Metric and Engl ish dimensions of various sizes of consumer packages for strawberries

Measurement

One-half 1iter

Liter

Pint

Quart

Volume:

Cubic inches

Cubic centimeters

30.5

500

$3-3 / 4$

Inches

Centimeters

Top width:

Inches

Centimeters

Bottom length:

\section{Inches}

Centimeters

Bottom width:

Inches

Centimeters

Depth:

Inches

Centimeters
$3-5 / 8$

9.2

$2-31 / 32$

7.5

$2-27 / 32$

7.2

$2-13 / 16$

7.1
61.2

1000

$7-1 / 4$

18.4

$3-3 / 4$

9.5

$5-11 / 16$

14.4

$2-31 / 32$

7.5

$2-27 / 32$

7.2

$2-31 / 32$

7.5

2-13/16

7.1
$3-3 / 32$

$3-3 / 32$

7.9

7.9
$5-11 / 16$

14.4
$9.2 \quad 9.5$

$2-31 / 32$

7.5

$9.5 \quad 18.4$

$-3 / 4$

$550.6 \quad 1101.2$

\section{DISCUSSION}

Changing sizes of shipping containers for fresh fruits and vegetables from the present proliferation to four sizes that fit on a $120-$ by $100-\mathrm{cm}$ (47.2- by 39.4-inch) base will result in more efficient handling after the containers arrive at a receiver's facility and until the containers reach the retail outlet. Standardization of containers may require some changes in packing machinery and packing line conveyor facilities, which could involve an initial cost to the packer-shipper; however, these costs likely will be more than offset by savings realized after packing. For example, shipping containers should become less costly as manufacturers concentrate their production on a few sizes. Also, with foreign markets playing an increasingly important part in American agriculture, U.S. growers may be required to use shipping containers that meet international standards if they wish to export their products. Growers' use of metric containers in domestic shipping will facilitate entry into these foreign markets. 